\title{
Spatial patterns of diversity at local and regional scales in a tropical lagoon
}

\author{
José Adán Caballero-Vázquez ${ }^{1,2}$ and María Eugenia Vega-Cendejas ${ }^{1}$
}

\begin{abstract}
The present study reports estimates of alpha $(\alpha)$, beta $(\beta)$ and gamma $(\gamma)$ diversity for the fish community of Chacmochuch Lagoon (SE Mexico), a natural protected area located in the northern portion of the Mesoamerican Barrier Reef System. Fish specimens were sampled in 2004 and 2006. Field work was carried out at three climatic peaks: at 13 stations using a $70 \mathrm{~m}$-long beach seine. The collected data were supplemented with information obtained from a previous work conducted in 2002 and were then analyzed with multivariate statistical methods. In addition, fish composition results from this study were compared to those reported for other similar ecosystems of the region. A total of 68 fish species were recorded, determined as peripheral (high-salinity species, usually marine affinity) most of them. Most of the fish species collected were determined as rare, and a few number of species were determined as common and dominant. Salinity, TSD, temperature, dissolved oxygen and other variables were measured to determine the influence over the fish communities, four groups of sites where determined. Results indicated a gradual decrease in the degree of species replacement towards the interior of the system (away from the coast). The estimated value of gamma diversity was high compared to that reported for other coastal systems of the region and, due to the high degree of habitat heterogeneity found in this system; beta diversity had a greater contribution to gamma diversity than alpha diversity. This lagoon acts as a nursing area for many of the fish species collected in this study as indicated by the presence of juvenile stages.
\end{abstract}

En el presente estudio, se midió y se determinó la biodiversidad alfa $(\alpha)$, beta $(\beta)$ y gamma $(\gamma)$ de la comunidad de peces en el Sistema Lagunar Chacmochuch, un Área Natural Protegida (ANP) localizada en la zona norte del Sistema Arrecifal Mesoamericano. El trabajo de campo se realizó en 13 sitios de muestreo durante los ciclos anuales 2004 y 2006, considerando los tres picos climáticos representativos de la región. Para la captura se utilizo un chinchorro de $70 \mathrm{~m}$ de largo. La matriz de información utilizada para el análisis se complemento con datos obtenidos a partir de un trabajo realizado durante el periodo 2002. Análisis multivariados fueron utilizados para la generación de resultados. Los resultados de la composición de peces se compararon con los reportados para otros ecosistemas similares de la región. Un total de 68 especies fueron registradas siendo periféricas (especies de alta salinidad y afinidad marina) la mayoría de ellas. Del registro, la mayoría de las especies se determinaron como especies raras, un número menor fueron especies comunes y dominantes. La salinidad, SDT, temperatura, oxigeno disuelto y otras variables fueron medidas para determinar su efecto sobre la comunidad de peces, encontrando cuatro agrupaciones de sitios. Los resultados indican una disminución gradual de las especies hacia el interior del sistema (al alejarse de la costa). La diversidad gamma es alta comparada a otros sistemas costeros de la región; sin embargo la taza de recambio beta es la que determina su alta heterogeneidad. Especies en estadios juveniles y de importancia económica fueron dominantes en el sistema, lo que determinan la zona como un área de crianza.

Key words: Alpha, beta and gamma diversity, Caribbean, Ichthyofauna, Mexico, Natural protected area.

\section{Introduction}

Species diversity is a basic parameter used for ecosystem evaluation, conservation, and management (Franklin, 1993; Harris et al., 1996; Nagelkerken et al., 2000b). Nonetheless, the numerical methods which are used to estimate species diversity have changed drastically due to recent advances in ecology (Franklin, 1993), and such new procedures have allowed the estimation of species diversity at multiple spatial scales. These approaches have underlined the importance of analyzing and protecting biodiversity at the habitat, ecosystem, and landscape levels (Franklin, 1993).
Biodiversity is the variability among living organisms from all sources including, terrestrial organisms, marine, and other aquatic ecosystems, this includes diversity within and between species, and of ecosystems (Naeem \& Wrigth, 2003). Biodiversity can be divided into three components: alpha (local diversity), beta (degree of species replacement among different habitats), and gamma (global diversity of the entire landscape) (Whittaker, 1972), all of which are measured in the same way and can be applied across different scales (Magurran, 2004). However, most of our understanding on biodiversity is based on estimates of alpha diversity (i.e., local diversity), ignoring the hierarchical spatial organization

${ }^{1}$ Centro de Investigación y de Estudios Avanzados del Instituto Politécnico Nacional (CINVESTAV), Unidad Mérida. A.P. 73, 97310 Mérida, Yucatán, México. adan07@gmail.com (JACV); maruvega@mda.cinvestav.mx (MEVC)

${ }^{2}$ Centro de Investigaciones Científicas de Yucatán (CICY), Unidad de Ciencias del Agua. CP 77524, Cancún, Quintana Roo, México. 
of biodiversity. Such an approach is a major shortcoming to our understanding of biodiversity, since higher-order components of diversity are influenced by ecological and biogeographical process which do not act at the local scale. Because overall biodiversity is maintained by such processes, conservation actions based on measurements conducted at only one spatial scale can lead to ineffective strategies. In this way, analyses of biodiversity simultaneously conducted at several spatial scales have been essential to understand the contribution of large-scale processes to local biodiversity patterns, and have served to elucidate the connection between local and regional species richness (Ricklefs \& Schluter, 1993; Gaston, 2000; Nogués-Bravo et al., 2008).

Coastal lagoons are essential components of coastal regions. They are defined as littoral water bodies formed by numerous habitats which vary in terms of the type of vegetation (e.g., mangrove, seagrass), salinity, and type of bottom cover. Coastal lagoons typically receive large nutrient and energy inputs from adjacent ecosystems, and maintain a temporary or permanent connection with marine areas (Nagelkerken \& van der Velde, 2002; Nagelkerken et al., 2002). Due to their high degree of environmental heterogeneity, as well as multiple feedbacks and connections with adjacent areas, coastal lagoons are fundamental for the preservation of biodiversity (Day \& Yáñez-Arancibia, 1985; Dorenbosch et al., 2005).

Unfortunately, the exponential growth and development of human populations in coastal areas has resulted in significant impacts on biodiversity (Ricklefs \& Schluter, 1993; Halffter, 1998; Moreno \& Halffter, 2001) due to various types of disturbances which have led to biological degradation of ecosystems which are adjacent to populated areas (Halffter, 1998; Avilés-Torres et al., 2001; Moreno \& Halffter, 2001). Ironically, the same characteristics which make these systems especially rich in terms of biodiversity (e.g., habitat heterogeneity, connectance), also make them highly susceptible to human impacts (Rodríguez \& Lewis, 1994). Moreover, compared to terrestrial ecosystems, the loss of biodiversity in lagoons and other aquatic systems has been largely overlooked (Hawksworth, 1995; Huston, 2003; Soberón \& Koleff, 1999; Sosa-Escalante, 2004), despite the fact that the degradation of these systems has been recognized as a large-scale environmental problem (Nagelkerken et al., 2000b).

Fish communities in coastal systems are composed of pelagic, benthic, and seasonal, residents (species that enter in the system to feed or reproduce and then disperse outside the lagoon or reef sea area to complete their life stage) (Pihl et al., 1994). The abundance and diversity of fish in these systems is affected by the habitats (Nagelkerken et al., 2000b), where the physical and chemical factors such as depth, degree of wave exposure, temperature, and salinity, determine the zonation and the structural heterogeneity of habitat in lagoons and reef systems, which largely controls the composition and diversity of fish species in a certain area (Meekan et al.,1995 and Jankowski et al., 2009). Dynamics and wave exposure is another factor (Fulton et al., 2005).

The aim of the present study was to estimate alpha $(\alpha)$, beta $(\beta)$, and gamma $(\gamma)$ diversity of the fish community present at the coastal lagoon of Chacmochuch (southeast Mexico). Also, the influence of physicochemical variables (annual cycles) on the abundance and richness of composition of local species was evaluated, considering the fish as an indicator group.

\section{Materials and Methods}

Study area. The Natural Protected Area (NPA), Chacmochuch lagoon $\left(21^{\circ} 10^{\prime} 53^{\prime \prime} \mathrm{N} 86^{\circ} 48^{\prime} 45^{\prime \prime} \mathrm{W}\right.$ and $\left.21^{\circ} 15^{\prime} 14^{\prime \prime} \mathrm{N} 86^{\circ} 51^{\prime} 29^{\prime \prime} \mathrm{W}\right)$ is located northeast of the city of Cancun, Mexico, within the Caribbean biogeographic province, and in the northern portion of the Mesoamerican Barrier Reef System (Almada-Villela et $a l ., 2002)$. It has a total area of 11,527 ha (Universidad de Quintana Roo, 1999), and presents a zone that is under marine influence conformed by 1) stations: $\mathrm{Ch} 1, \mathrm{Ch} 2, \mathrm{Ch} 3, \mathrm{Ch} 4, \mathrm{Ch} 5$, Ch6, and Ch7 of Chacmochuch bay); 2) a zone named Ria Nagigo (R), and 3) eight principal lagoons, all of the above are surrounded by mangrove forests (Rhizophora mangle, Laguncularia racemosa, Avicennia germinans, and Conocarpus erectus): conformed by Larga (L), Punta Sam (S), Las Garzas (G), Cocodrilos (C), Zapatito (Z), Esmeralda (E), Manati (M), and La Esperanza (E) (Fig. 1; Table 1). The weather in this region is hot and subhumid, with a mean annual temperature of $27^{\circ} \mathrm{C}$, and a mean annual rainfall of $1300 \mathrm{~mm}$. The system's maximum depth is $5 \mathrm{~m}$ ( $1 \mathrm{~m}$ on average), and the tide regime has only a moderate influence on ecosystem processes. Bottom cover types range from seagrass areas (Thalassia testudinum being the most common species, followed by Syringodium filiforme), to exposed sandy substrates, patches with both, sea grasses, and algae, as well as hard-bottom areas.

Sample collection. Data from this study were collected in 2004 and 2006, and combined with a data set from a previous work conducted in 2002 (Caballero-Vázquez et al., 2005). Field work was carried out at three climatic peaks: in March (driest), June (rainiest), and September (coldest). In both studies, a total of 13 sampling stations were established at representative areas of the system, in terms of bottom type, depth, and distance from the mouth of Chacmochuch Bay on the Caribbean Sea (Fig. 1). The same methodology was used for samples collected from 2002 to 2006; one sampling for each site in three climatic peaks, for 3 annual cycles.

Quantitative sampling at each station was done with a 2.5-m high, 70-m long, and 1.5-cm mesh seine net (one sample per site per period). Collected specimens were identified using specialized bibliography and deposited as vouchers at the fish collections of ECOSUR-Chetumal (ECO-CH) and CINVESTAV-Merida (CINV-NEC). In addition, surface and bottom physicochemical parameters were recorded at each station using a multiparametric probe YSI 6600. These variables were: temperature, salinity, dissolved oxygen, $\mathrm{pH}$, turbidity, chlorophyll, nitrogen, TSD, ammonium, nitrates, phosphorous, depth, and clarity. Fish species were grouped as primary, secondary, and peripheral (Table 1) based on 


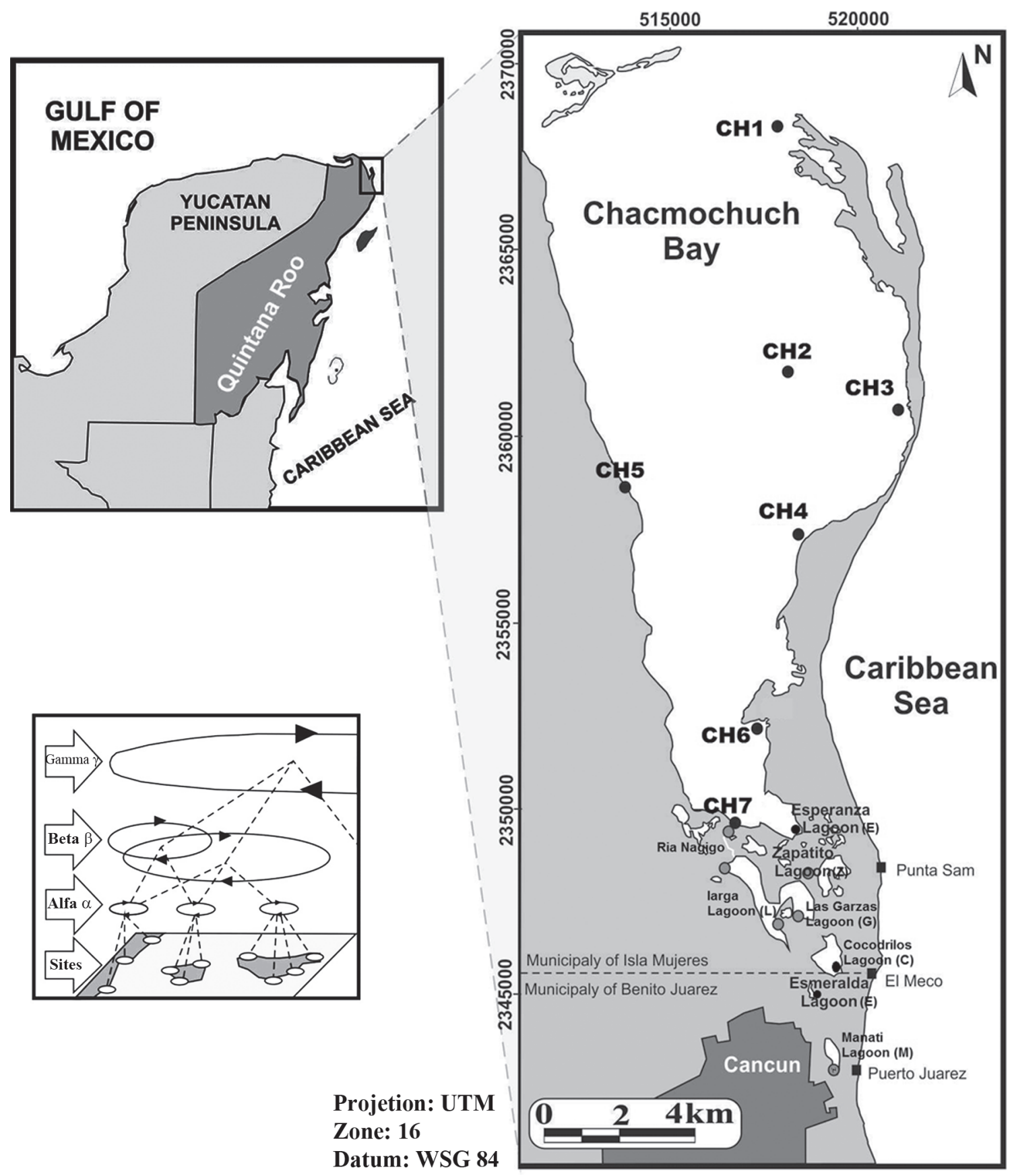

Fig. 1. Map showing the localization of Chacmochuch Lagoon System, and the biodiversity levels (alpha, beta and gamma) in the system. The location of sites is indicated in the figure.

their tolerance to salinity, using the criteria proposed by Castro-Aguirre et al.(1999).

To validate the data set, species richness was estimated with species accumulation curves based on 1000 sample-based randomizations (EstimateS V. 8, Colwell, 1994-2004) and the rarefaction method (Primer V. 5.2, Clarke \& Gorley, 2001). Species accumulation curves based on the sampling effort were compared to the estimated values of an exponential equation using the following formula:

$$
S(t)=a / b(1-\exp (-b t))
$$

where $\mathrm{S}(\mathrm{t})$ is the expected species richness, $\mathrm{t}=$ is the effort (man-hours), and $\mathrm{a}$ and $\mathrm{b}$ are parameters that determine the speed at which saturation in species richness is reached (Soberón \& Llorente, 1993).

Both a binary matrix (species presence/absence) and a richness matrix (number of species) were constructed for each sampling station. To statistically define the degree of homogeneity or heterogeneity between sampling in $\mathrm{H}^{\text {' }}$ diversity (Shannon-Wiener index), a modified " $t$ "-test (Hutcheson, 1970) was conducted. Hill (1973) diversity 
numbers were used to calculate the effective contribution of every species in each sample based on its abundance. Analyses were conducted using BIODIV 5.1 (Baev \& Penev, 1995). All tests considered a significance level of $\alpha<0.05$.

As a measure of beta diversity (turnover rate) of the species that are won and lost from one site to another, a Non-Metric Multi-Dimensional Scaling (NMDS) was used to determine the influence of physicochemical variables on fish composition and abundance, through a dissimilarity analysis. Significant differences of variables analyzed were determined. These analyses were conducted with diversityvegan, version 2.11 .1 of the " $R$ " program (R Development Core Team, 2010).

Beta diversity. Species replacement between sampling stations was measured with the Cody (1975) index, which is expressed as species gained or lost when moving between stations. This index is computed in the following way:

$\mathrm{BC} 1=[\mathrm{g}(\mathrm{H})+\mathrm{l}(\mathrm{H})] / 2$, where $\mathrm{BC} 1=$ Cody index, $\mathrm{g}(\mathrm{H})=$ number of species present in habitat 1 but absent in habitat 2 (species gained) and $\mathrm{I}(\mathrm{H})=$ number of species absent in habitat 1 but present in habitat 2 (species lost). The resulting values were employed to create a triangular matrix which was then used to conduct a cluster analysis (flexible sorting, Bray Curtis similarity) to determine associations between stations in terms of fish abundance. Cody index validation as a basic definition of beta analysis was recently established by Tuomisto (2010a, 2010b).

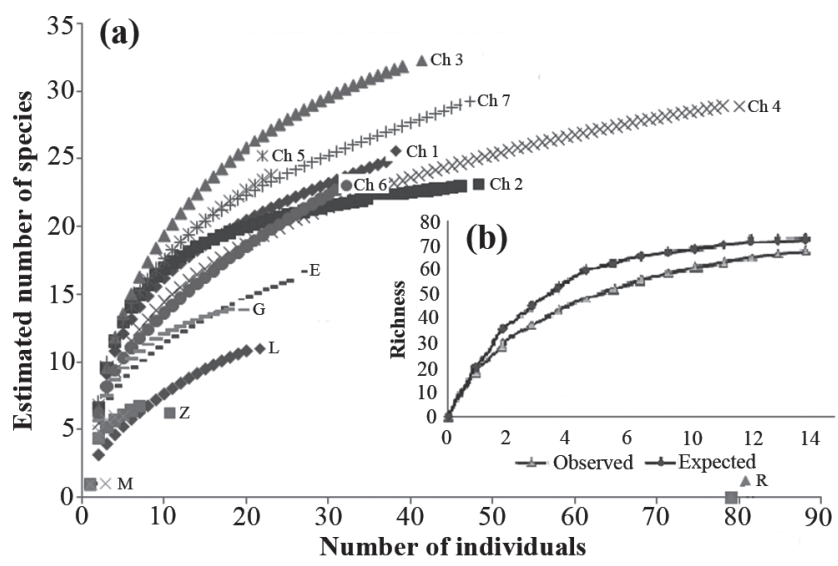

Fig. 2. (a) Rarefaction plots $(\mathrm{Ch} 1=25 \mathrm{spp}, \mathrm{Ch} 2=23, \mathrm{Ch} 3=32$, Ch4=29, Ch5=23, Ch6=22, Ch7=29, E=16, G=14, L=11, Z=7, $\mathrm{R}=2, \mathrm{M}=4$ ) and estimated species with a standardized sample of 1000 individuals. Sites name's abbreviation defined in table 1. (b) Species-effort curve obtained from Chacmochuch Lagoon System. Curve Intersection (a) $=6.06$, curve slope (b) $=0.27$, Dear range of gamma diversity of the landscape (a/ b) $=22.17$, probability value $(p)=0.001$, sampling efficient $\%$ $(\mathrm{MS}=97$, days number to reach $90 \%$ (arbitrary value) of the gamma diversity of the landscape $(\mathrm{T})=27$.
Gamma diversity. Schluter \& Ricklefs (1993) proposed the measurement of gamma diversity based on components alpha, beta, and the spatial dimension.

$$
\Gamma=\alpha \times \beta \times N
$$

where:

$\Gamma=$ gamma diversity;

$\alpha=$ average number of species in a community;

$\beta=$ the inverse of the species dimension; that is, $1 /$ the mean presence of communities or locations occupied by a species;

$\mathrm{N}=$ total number of communities.

To calculate $\gamma$, the total number of species present in each habitat (ni) was divided by the total number of species present in the landscape (n) and elevated to -1 (Sosa-Escalante, 2004) using the following formula:

$$
\mathrm{b}=[(\mathrm{n} 1+\mathrm{n} 2+\mathrm{n} 3+\ldots \mathrm{ni}) / \mathrm{n})]-1
$$

\section{Results}

Specie richness. Species accumulation curves and bootstrap analyses showed that the sampling effort adequately represented species richness of each site. The number of collected species was close to the estimated value based on the expected species richness model (Fig. 2a, b). A total of 4500 specimens were collected belonging to 68 species, 50 genera, and 34 families; 20 species represented $90 \%$ of the total abundance (Table 1), while $88.2 \%$ of the total number of species were defined as peripheral and $11.8 \%$ as secondary. No primary species were found in Chacmochuch (Fig. 3).

Among the collected species, Gerres cinereus, Floridichthys polyommus, Archosargus rhomboidalis, Anchoa parva, Sphyraena barracuda, and Harengula jaguana were the most abundant ( $>66 \%$ of all specimens collected) (Table 1). Strongylura notata, Sphoeroides testudineus, and Lactophrys quadricornis were recorded at 8 out of 13 sampling sites; although their abundance was lower (Table 1).

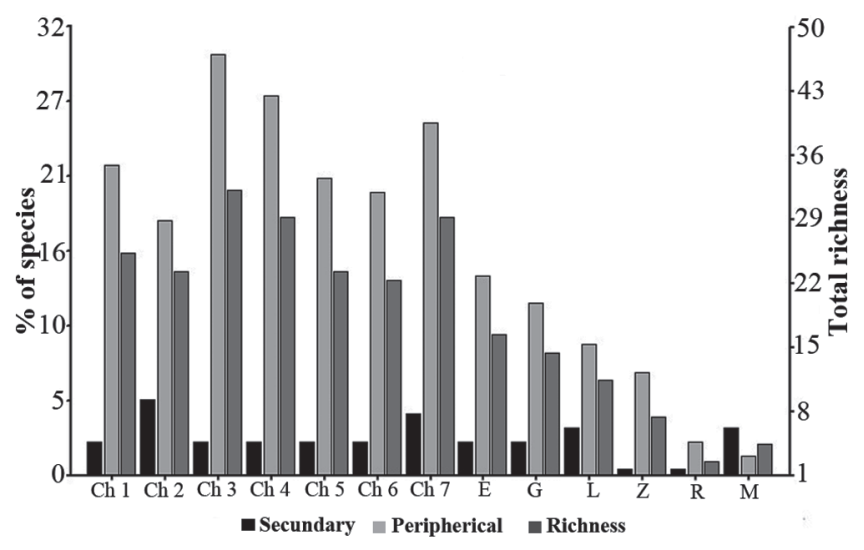

Fig. 3. Ecological composition of fishes in Chacmochuch Lagoon System and total richness, secondary and peripherical species are shown. 
Table 1. Fish species, abbreviations of the species, collection sites, abundance (\%) and ecological group (P: primary; strictly freshwater, S: secondary; brackish water species and P: peripheral; high-salinity species, usually marine affinity) in Chacmochuch Lagoon System. Sites 1, 2, 3, 4, 5, 6 and 7 are of Chacmochuch bay; E=Laguna Esperanza, G=Laguna Garzas, L=Laguna Larga, $\mathrm{Z}=$ Laguna Zapatito, $\mathrm{R}=$ Ría Nagigo and $\mathrm{M}=$ Laguna Manatí. Fish species order is according to their abundance (\%).

\begin{tabular}{|c|c|c|c|c|}
\hline Species & Abbreviations & Sites & Abundance & Ecological Group \\
\hline Acanthostracion polygonia & Lp & 1 & 0.027 & $\mathrm{P}$ \\
\hline Acanthostracion quadricornis & $\mathrm{Lq}$ & $1-7, \mathrm{G}$ & 3.29 & $\mathrm{P}$ \\
\hline Aluterus schoepfi & As & 6 & 0.027 & $\mathrm{P}$ \\
\hline Anchoa parva & Ap & $1-7, \mathrm{E}, \mathrm{G}, \mathrm{L}$ & 8.24 & $\mathrm{P}$ \\
\hline Apogon aurolineatus & $\mathrm{Au}$ & 7 & 0.027 & $\mathrm{P}$ \\
\hline Archosargus rhomboidalis & $\mathrm{Ar}$ & $01 /$ jul & 10 & $\mathrm{P}$ \\
\hline Atherinomorus stipes & At & $1,3,4,5,7$ & 1.34 & $\mathrm{P}$ \\
\hline Bothus ocellatus & Bo & 4,6 & 0.081 & $\mathrm{P}$ \\
\hline Calamus penna & $\mathrm{Ce}$ & 3,5 & 0.054 & $\mathrm{P}$ \\
\hline Cantherhines pullus & $\mathrm{Cu}$ & 7 & 0.027 & $\mathrm{P}$ \\
\hline Caranx latus & $\mathrm{Ca}$ & $1,3,4,7, \mathrm{G}, \mathrm{L}$ & 0.81 & $\mathrm{P}$ \\
\hline Centropomus undecimalis & $\mathrm{Cn}$ & G,Z,R & 0.081 & $\mathrm{P}$ \\
\hline Chaetodon capistratus & $\mathrm{Cc}$ & 3 & 0.027 & $\mathrm{P}$ \\
\hline Chilomycterus antennatus & $\mathrm{Ch}$ & 2,4 & 0.081 & $\mathrm{P}$ \\
\hline Chilomycterus antillarum & $\mathrm{Ct}$ & 4,5 & 0.054 & $\mathrm{P}$ \\
\hline Chilomycterus schoepfi & Cs & $1-7, \mathrm{Z}$ & 1.13 & $\mathrm{P}$ \\
\hline Chriodorus atherinoides & $\mathrm{Ci}$ & 1,3 & 0.22 & $\mathrm{P}$ \\
\hline Cichlasoma urophthalmus & $\mathrm{Cr}$ & $7, \mathrm{G}, \mathrm{M}$ & 0.70 & $\mathrm{~S}$ \\
\hline Cosmocampus elucens & $\mathrm{Cm}$ & 3,7 & 0.081 & $\mathrm{P}$ \\
\hline Cynoscion nebulosus & $\mathrm{Cb}$ & $3,7, \mathrm{R}$ & 0.16 & $\mathrm{P}$ \\
\hline Cyprinodon artifrons & $\mathrm{Cf}$ & $1, \mathrm{E}$ & 0.054 & $\mathrm{~S}$ \\
\hline Dasyatis americana & $\mathrm{Da}$ & 1,4 & 0.081 & $\mathrm{P}$ \\
\hline Decapterus punctatus & Dp & $\mathrm{L}$ & 0.054 & $\mathrm{P}$ \\
\hline Eucinostomus argenteus & $\mathrm{Ea}$ & $5,6,7$ & 0.75 & $\mathrm{P}$ \\
\hline Eucinostomus gula & Eg & 6 & 0.054 & $\mathrm{P}$ \\
\hline Eugerres plumieri & Ep & $2,4,7, \mathrm{E}, \mathrm{G}, \mathrm{Z}$ & 3.92 & $\mathrm{P}$ \\
\hline Floridichthys polyommus & $\mathrm{Fp}$ & 1-7,E,G & 12 & $\mathrm{~S}$ \\
\hline Gambusia sexradiata & Gs & 2 & 0.027 & $\mathrm{~S}$ \\
\hline Gambusia yucatana & Gy & $2, \mathrm{M}$ & 0.67 & $\mathrm{~S}$ \\
\hline Garmanella pulchra & Gp & 7,L & 0.162 & $\mathrm{~S}$ \\
\hline Gerres cinereus & Gc & 1-7,E,G,L,Z & 21.59 & $\mathrm{P}$ \\
\hline Haemulon aurolineatum & $\mathrm{Ha}$ & $3, \mathrm{E}$ & 0.57 & $\mathrm{P}$ \\
\hline Haemulon parra & Нр & $3,4,5, \mathrm{E}$ & 0.32 & $\mathrm{P}$ \\
\hline Haemulon plumierii & $\mathrm{Hi}$ & $2,3,6, \mathrm{E}$ & 0.51 & $\mathrm{P}$ \\
\hline Harengula clupeola & $\mathrm{Hc}$ & $3,5,7, \mathrm{~L}$ & 1.97 & $\mathrm{P}$ \\
\hline Harengula jaguana & $\mathrm{Hj}$ & $1-4,6, \mathrm{E}, \mathrm{Z}$ & 7.21 & $\mathrm{P}$ \\
\hline Heterandria bimaculata & $\mathrm{Hb}$ & $3,5,6, \mathrm{~L}, \mathrm{M}$ & 0.48 & $\mathrm{~S}$ \\
\hline Hipросатриs erectus & $\mathrm{He}$ & 1,4 & 0.054 & $\mathrm{P}$ \\
\hline Hyporhamphus unifasciatus & $\mathrm{Hu}$ & $1,2,4-7$ & 0.73 & $\mathrm{P}$ \\
\hline Lactophrys trigonus & $\mathrm{Lt}$ & $1,3,5$ & 0.19 & $\mathrm{P}$ \\
\hline Lucania parva & $\mathrm{La}$ & $4,6,7$ & 0.162 & $\mathrm{P}$ \\
\hline Lutjanus analis & Ln & 4 & 0.027 & $\mathrm{P}$ \\
\hline Lutjanus apodus & Lo & $4,7, \mathrm{G}$ & 0.19 & $\mathrm{P}$ \\
\hline Lutjanus griseus & Lg & $02 / \mathrm{jul}$ & 1.05 & $\mathrm{P}$ \\
\hline Megalops atlanticus & $\mathrm{Ma}$ & 3,7,E,G,Z & 0.29 & $\mathrm{P}$ \\
\hline Monacanthus ciliatus & $\mathrm{Mc}$ & 3 & 0.081 & $\mathrm{P}$ \\
\hline Mugil cephalus & $\mathrm{Me}$ & $1,4,5,6, \mathrm{G}$ & 0.48 & $\mathrm{P}$ \\
\hline Mugil curema & $\mathrm{Mu}$ & 40330 & 0.70 & $\mathrm{P}$ \\
\hline Ocyurus chrysurus & $\mathrm{Oc}$ & 3 & 0.054 & $\mathrm{P}$ \\
\hline Opsanus beta & $\mathrm{Ob}$ & E & 0.027 & $\mathrm{P}$ \\
\hline Poecilia mexicana & $\mathrm{Pm}$ & 2 & 0.54 & $\mathrm{~S}$ \\
\hline Poecilia orri & Po & 4,7 & 0.054 & $\mathrm{~S}$ \\
\hline Poecilia velifera & $\mathrm{Pv}$ & $2, \mathrm{~L}$ & 2.84 & $\mathrm{~S}$ \\
\hline Prionotus tribulus & $\mathrm{Pt}$ & 5 & 0.027 & $\mathrm{P}$ \\
\hline Sardinella aurita & $\mathrm{Sa}$ & 7 & 1.27 & $\mathrm{P}$ \\
\hline Scomberomorus regalis & $\mathrm{Sr}$ & 2,G,Z,M & 0.65 & $\mathrm{P}$ \\
\hline Selene vomer & $\mathrm{Sv}$ & 2,7 & 0.081 & $\mathrm{P}$ \\
\hline Sparisoma aurofrenatum & $\mathrm{Sp}$ & 3 & 0.054 & $\mathrm{P}$ \\
\hline Sparisoma radians & $\mathrm{Sd}$ & 1,3 & 0.081 & $\mathrm{P}$ \\
\hline Sphoeroides nephelus & Sn & 5 & 0.027 & $\mathrm{P}$ \\
\hline Sphoeroides spengleri & Ss & 2,4,7,E,L & 0.29 & $\mathrm{P}$ \\
\hline Sphoeroides testudineus & St & $1,2,4,6,7, \mathrm{E}, \mathrm{G}, \mathrm{L}$ & 3.27 & $\mathrm{P}$ \\
\hline Sphyraena barracuda & $\mathrm{Sb}$ & 1-7,E,G,L & 7.54 & $\mathrm{P}$ \\
\hline Strongylura notata & So & 1-7,E & 1.62 & $\mathrm{P}$ \\
\hline Strongylura timиси & $\mathrm{Si}$ & $1,3,6, \mathrm{E}$ & 0.32 & $\mathrm{P}$ \\
\hline Syngnathus scovelli & Sy & 5 & 0.081 & $\mathrm{P}$ \\
\hline Synodus intermedius & $\mathrm{Se}$ & 3,4 & 0.135 & $\mathrm{P}$ \\
\hline Urobatis jamaicensis & $\mathrm{Uj}$ & 1,3 & 0.135 & $\mathrm{P}$ \\
\hline
\end{tabular}


Table 2. Diversity Index and ecological parameters obtained for each sampling site of Chacmochuch lagoon System. (Ch1-Ch7 sites of Chacmochuch bay; E, G, L, Z, R and M are sites of the system, name's abbreviations are defined in Table 1). 's=richness, $\mathrm{d}=$ diversity, $\mathrm{H}^{\prime}=$ Shannon-Wiener index, $\mathrm{N} 1=$ number of species of fish with average abundance, $\mathrm{n} 2=$ =number of very abundant species, $\mathrm{N} 3=$ number of rare species.

\begin{tabular}{cccccccccccccc}
\hline Sample & Ch 1 & Ch 2 & Ch 3 & Ch 4 & Ch 5 & Ch 6 & Ch 7 & E & G & L & Z & R & M \\
\hline 's & 25 & 23 & 32 & 29 & 24 & 23 & 29 & 16 & 14 & 11 & 7 & 5 & 6 \\
d & 4.062 & 3.596 & 5.2 & 4.206 & 4.243 & 3.837 & 4.58 & 2.735 & 2.517 & 1.887 & 1.417 & 1.516 & 1.292 \\
H' & 2.403 & 2.427 & 2.445 & 2.041 & 2.463 & 2.234 & 2.554 & 2.001 & 2.023 & 1.175 & 1.539 & 1.433 & 1.653 \\
N1 & 11.05 & 11.32 & 11.53 & 7.7 & 11.74 & 9.335 & 12.86 & 7.396 & 7.561 & 3.237 & 4.662 & 4.19 & 5.225 \\
n2 & 8.109 & 7.536 & 6.447 & 4.296 & 8.42 & 7.157 & 9.333 & 5.598 & 5.691 & 2.517 & 3.984 & 3.769 & 4.645 \\
N3 & 5.493 & 3.691 & 3.031 & 2.282 & 4.708 & 4.176 & 4.566 & 3.171 & 3.302 & 2.02 & 2.875 & 2.8 & 3 \\
\hline
\end{tabular}

Local diversity. The Shannon-Wiener index (H'n) showed a high degree of spatial variation during the years with values ranging from 1.18 to 2.55 bits $\cdot$ ind $^{-1}$ (Table 2). Sites located in the marine zone showed the highest species diversity values (Ch7, Ch5, Ch3, Ch2, and Ch1, ordered from highest to lowest), and it was also in this area where connectivity and exchange of lagoon and reef fish species was greater. On the other hand, the Zapatito and Manati lagoons, as well as Ria Nagigo showed homogeneous conditions regarding species richness and the greatest evenness (Table 2).

Heterogeneity in the system and groups associations. Results from the NMDS analysis showed four groups of sites (Fig. 4). One group included Chacmochuch Bay (1 to 7) and the Esperanza lagoon, this group was determined by variables such as temperature $(\mathrm{P}=0.029)$, ammonium $\left(\mathrm{P}=0.011^{*}\right)$, salinity $\left(\mathrm{P}=0.001^{*}\right)$, TDS $\left(\mathrm{P}=0.001^{*}\right)$, and $\mathrm{pH}$ $(\mathrm{P}=0.254)$. A second group included the Garzas and Zapatito lagoons, and was determined by depth $(\mathrm{P}=0.12)$ and temperature. A third group consisted of Larga and Manati lagoons for which chlorophyll $\alpha(\mathrm{P}=0.03 *)$, turbidity $(\mathrm{P}=0.01 *)$, oxygen $\left(\mathrm{P}=0.030^{*}\right)$, and nitrates $(\mathrm{P}=0.079)$ were the variables that determined the group's structure. The last group only included Ria Nagigo which exhibited particular combinations of temperature and depth, and was also influenced by tides; such conditions made this site different from all others in the system $(*$ denotes significant differences).

The abundance index (Hill numbers) indicated that $\mathrm{Ch} 7$, $\mathrm{Ch} 1$, and $\mathrm{Ch} 5$ (with marine influence) had the greatest number of species with medium and high abundances $(\mathrm{N} 1, \mathrm{~N} 2)$, as well as the greatest amount of rare species and a lower rate of replacement (Fig. 5, Table 2). In contrast, Laguna Larga, Ria Nagigo, and Zapatito exhibited the lowest number of species with medium and high abundances. The estimated value of gamma diversity in the system was 68 species $(18.23 \times 0.029 \mathrm{x}$ 13); diversity values are presented in Table 3.

\section{Discussion}

The present work adds important information to that reported in previous studies which have described the fish species composition of Chacmochuch lagoon at different sites within this system (Caballero-Vázquez et al., 2005). However, this study not only describes species composition but also provides estimates of species diversity at several spatial scales (e.g., the degree of fish species replacement across sampling sites). The aim of the study was to estimate alpha $(\alpha)$, beta $(\beta)$, and gamma $(\gamma)$ diversity of the fish community. In addition, we used multivariate statistical methods to determine the influence of physicochemical variables on spatial patterns of species distribution and associations. In this way, the present study has increased the current knowledge on coastal lagoon systems such as Chacmochuch, providing information that underlines the importance of conducting biodiversity analyses at more than one spatial scale.

Fish species diversity. Species richness has been commonly used as a surrogate of fish species diversity in coastal systems. In the case of Chacmochuch, fish species diversity was higher than that previously reported for an adjacent system composed of the lagoons of Nichupte and Bojorquez, where a total of 37 fish species were recorded (Reséndez-Medina, 1975). Other lagoons in the region such as the Pajarera and Yalahau have shown lower fish richness compared to Chacmochuch. For example, V. D. García-Hernández (unpublished data) reported 43 species for Pajarera, while M. E. Vega-Cendejas et al. (unpublished data) reported 28 species for Yalahau.However, another study by Ordoñez-Lopez \& Garcia-Hernandez (2005) reported 92 species for Yalahau, including fish larvae. Two additional studies conducted in the southern portion of the Mexican Caribbean reported 39 species for eight different coastal lagoons combined (Avilés-Torres et al., 2001), and 65 species for the small lagoon of río Huach (Avilés-Torres et al., 2001). In addition, (Schmitter-Soto et al., 2009) reported 188 species for the Chetumal bay, although 61 of these were collected as larvae. In should be noted that although the effort and sampling methods differ in each study, all papers reported the composition or species richness at each site and this allows a comparative analysis of species richness of this study to other similar sites. The result of saturation species curves found that biodiversity registered in Chacmochuch is representative of the area, according to species richness at each site, which validates the fishing net used. Our data suggest that the Chacmochuch lagoon may be richer than other similar coastal lagoon systems located throughout the Mexican Caribbean, and this may be due to its proximity to the Gulf of Mexico, and thus the possibility of species 


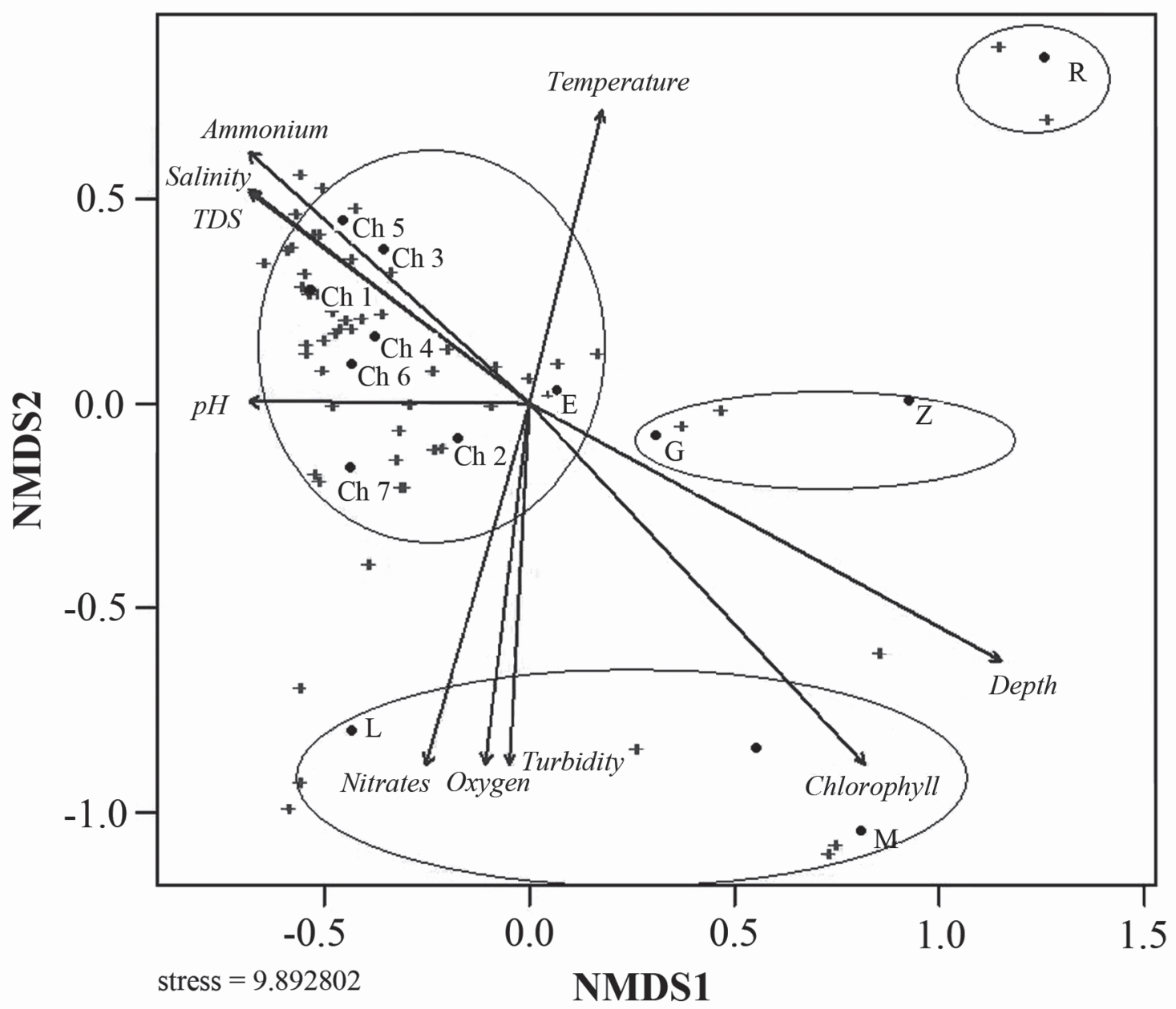

Fig. 4. n-MDS (non-metric Multi-Dimensional Scaling, Bottom) whit the effect of environmental variables during the annual cycle on the sites of Chacmochuch Lagoon System whit p-values of the total fish species (size of the line, determines the effect of variable. Circle diameters are sized in proportion to the variables effect in each site). For the analysis square root transformation was used and stepping across of 78 dissimilarities.

interchange between regions (Fig. 1). Both regions (Mexican Caribbean and Gulf of Mexico) are part of the Atlantic Ocean. Another explanation could be the elevated productivity of waters adjacent to the study system, coupled whit hydrobiological connectivity between mangrove systems, lagoon systems, grasslands, and marine area. Nonetheless, we caution on any further speculations because the sampling effort has been extremely different for most of the cited studies, and thus a valid comparison remains to be performed.

Environmental heterogeneity. Fish species diversity is influenced by salinity and temperature, these variables coupled with TSD, ammonium or oxygen exhibit their highest values near the marine coastal zone, and they are probably the primary driver of beta diversity among the lagoon system (Davidar, 2007). However, when fish biodiversity is estimated based in species that were found to group among the sampling sites analyzed, more complex ecological patterns arise compared to when fish community data are analyzed along environmental gradients. Such groups generate ecological information that shows the influence of natural and anthropogenic disturbances on fish community responses.

Results of our NMDS analyses suggest four groups of sites that were identified and corresponded to the classification defined in figure 4 . Chacmochuch bay sites 1 to 7 exhibited the highest level of species replacement. According to the turnover rate, a comb-shape gradient was observed, indicating that species replacement tends to decrease toward the interior portion of the lagoon. The same pattern was observed for alpha diversity values.

It is recognized that $\beta$-diversity will increase with habitat or environmental heterogeneity, and that species saturation will occur at successively smaller proportions of the regional pool (Loreau et al., 2001). Accordingly, in this study we found that $\alpha$-diversity was lower than $\beta$-diversity (Table 3 ), indicating that topographic and environmental heterogeneity 


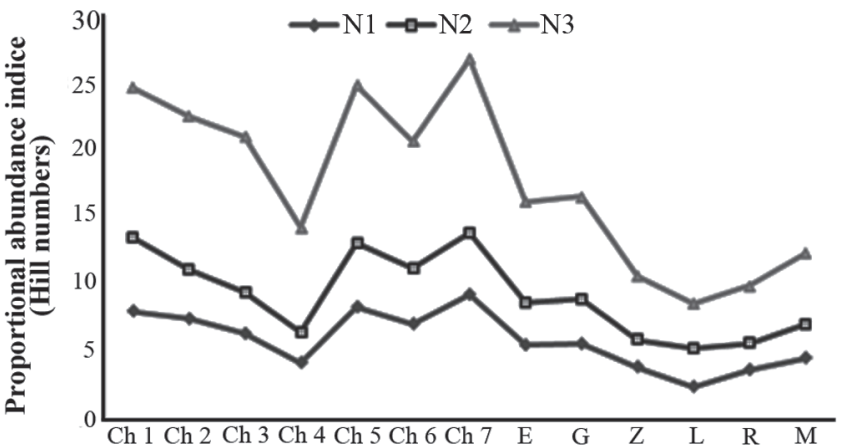

Fig. 5. Index of proportional abundance (series of Hill's number) for the habitats that conform the Chacmochuch lagoon System, indicating the number of species of fish with average abundance (N1), number of very abundant species $(\mathrm{N} 2)$ and the number of rare species $(\mathrm{N} 3)$.

are the most important factors driving variation in species richness and composition among the studied sites.

A comparative analysis between results obtained in this work from a lagoon system located in the north zone of the Mexican Caribbean and results from Avilés-Torres et al., (2001) obtained from a lagoon system located in the south zone of the Mexican Caribbean, showed that a higher alpha and beta diversity was found in the north zone as compared to the south zone (Table 3).

Our results support the view that Mexico is a "betadiverse country" (Soberón \& Koleff, 1999). Changes in $\beta$ diversity between the sampling stations showed that sites at Chacmochuch bay (Ch1- Ch7) exhibited the greatest values of species replacement over a latitudinal gradient (based on salinity, TSD, and temperature). Therefore, lagoon systems such as Chacmochuch represent key ecosystems for the maintenance of fish diversity in coastal environments such as those found in southeast Mexico. Moreover, in order to maintain beta and gamma diversity in these ecosystems, it will be necessary to protect both high and low diversity sites within a given system, since high levels of species interchange (i.e., $\beta$-diversity) occur between both types of sites, and it is this condition which determines local and regional diversity.

Descriptors such as topographic complexity, type of bottom cover, physicochemical characteristics, and connectivity among sites are variables that help explain community structure and species composition in aquatic environments such as Chacmochuch (Caballero-Vázquez et al., 2005). These variables define ecological niches and refuges where the probability of predation and competition is lower, which may result in an increase in species richness for the entire system.

In Chacmochuch, throughout the year there are species widely distributed in the system, in spite of habitat heterogeneity (determined by changes in salinity and the difference of habitats). A possible explanation for this pattern is the tolerance of dominant species to environmental conditions; most of the fishes in Chacmochuch are either marine euryhaline or freshwater
Table 3. Gamma diversity values obtained for Chacmochuch Lagoon System (north zone) and comparison of the values with Avilés-Torres et al. (2001) in río Huach Lagoon System (south zone) of the Mexican Caribbean.

\begin{tabular}{cc}
\hline \multicolumn{2}{c}{ Comparison of gamma diversity and his components } \\
North zone $($ Chacmochuch $)$ & South zone (río Huach) \\
\hline$\alpha$ (species $)=18.23$ & $\alpha$ (species $)=12.88$ \\
$\beta($ lagoons- 1$)=53.5$ & $\beta($ lagoons-1) $=0.38$ \\
$\gamma($ gamma $)=68$ & $\gamma($ gamma $)=39.0151$ \\
Sites $=13$ & Sites $=8$ \\
T (species $)=68$ & T (species $)=39$ \\
\hline
\end{tabular}

euryhaline (that is, secondary sensu Myers, 1938). On the other hand, of secondary and peripheral species, the groupings of fish (marine stenohalyne, marine euryhalyne, and freshwater) maintain their spatial distribution in the lagoon throughout the year, in spite of the changes in the environmental variables, possibly because the gradient of the salinity and other parameters remain in spite of those variations. Environmental variables in coastal ecosystems influence differently in every life form of species. In Chacmochuch, the salinity is one of the variables that could affect the fish composition in the system; the greater abundance of fish was recorded in environments near the sea area, zone that also has the greatest seasonal changes throughout the year.

Regional vs. local fish diversity. Recent studies have demonstrated that species richness within local communities can influence ecosystem functioning (e.g., productivity) and stability (Nagelkerken et al., 2000b). In this sense, environmental heterogeneity, which is responsible for beta and gamma diversity patterns, can have a relevant effect on the relationship between richness and ecosystem function (Loreau, 2000). The high degree of environmental heterogeneity observed at Chacmochuch suggests that species replacement at the local scale is the main determinant of regional diversity. This heterogeneity explain why sites such as Chacmochuch Bay (Ch1-Ch7, Fig 1) are able to support greater resistance and persistence change, together with connectivity with adjacent environments (mangrove, seagrass beds, and coral reefs) (Mumby et al., 2004). Nevertheless, habitat degradation and pollution at sites like the Manati and Larga lagoons are constant threats to productivity and biodiversity of ecosystems such as the Chacmochuch lagoon (Tilman, 2001; Loreau et al., 2001). If natural and anthropogenic impacts on this ecosystem continue, they may eventually lead to the irreversible degradation of the entire system (Jackson et al., 2001; Hughes etal., 2003).

Conservation of biodiversity. Connectivity in NPA is synonymous of biodiversity conservation for adjacent areas. Connectivity lowers predation and allows for more persistence and resilience of species and systems. Chacmochuch lagoon system acts as a nursery and feeding area for marine fish of Isla Contoy and other adjacent reefs in the zone. Therefore, it is important to maintain connectivity and biodiversity in the area. It is necessary to 
intensify actions to create an extended NPA which will include Chacmochuch lagoon system, Isla Contoy, and other systems. It is important to integrate the systems (lagoons, mangrove, seagrass, seaweed, reefs, and other wetlands), in order to maintain the sustainable use of biodiversity and ecosystem services.

Systems with such high beta diversity are common in the Caribbean, although little studied.They offer high benefit/ cost opportunities for conservation, particularly as climate change threatens to alter the species composition of communities of habitat specialists.

Lagoon systems are critical environments to live for many species they are characterized by being highly ecological and hydrological dynamic, which makes it difficult to elaborate predictions on long term ecosystem function or stability. In addition, ecosystem degradation and biodiversity loss in coastal lagoon systems such as: Nichupte and Bojorquez (northern zone), and Chetumal Bay (southern zone) are evident, but the lack of scientific information and adequate monitoring programs have limited the possibility of evaluating their condition in a systematic manner. For this reason, it is a conservation priority to assess the biodiversity of these systems before they are dramatically altered, and in this way generate baseline information for future studies. Although Chacmochuch is a natural protected area and as such has remained free of human impacts for the most part, it is located in the most important touristic region of Mexico and future tourist developments will threaten its current conservation status. Moreover, Chacmochuch also exhibits high connectivity with nearby ecosystems which are contaminated, and this makes it necessary to preserve the entire system and surrounding areas in order to maintain regional diversity. This finding should be taken into account when choosing core areas for conservation in this system, as both high diversity and low diversity habitats will contribute to beta diversity and thus be ecologically important and of regional conservation value in order to maintain overall species diversity. This work can be important to understand the state of conservation of the systems based on spatial patterns of diversity; findings of this type (Tables 2 and 3 ) represent valuable information which can be taken into account for the management and conservation of natural protected areas at a regional level.

\section{Acknowledgements}

This work was supported by a grant from Consejo Nacional de Ciencia y Tecnología de México (CONACyT) and by Centro de investigación y de Estudios Avanzados (CINVESTAV). The first author also thanks CONACyT for his PhD scholarship (185940), and World Wildlife Found (WWF, Russell E. Train Education for Nature Program) for the grant with agreement RM45. We also thank to M.C Jorge Montero, for his helpful assistance during fieldwork and Drs. Luis Capúrro, J. Jacobo Schmitter Soto, and Cecilia Hernandez-Zepeda for their critical reviews that improved the quality of this manuscript.

\section{Literature Cited}

Almada-Villela, P., M. McField, P. Kramer, P. R. Kramer \& J. E. Arias González. 2002. Status of coral reefs of Mesoamerica-Mexico, Belize, Guatemala, Honduras, Nicaragua and El Salvador. Pp. 303324. In: Wilkinson, C. R. (Ed.), Status of Coral Reefs of the World. GCRMN Report, Australian Institute of Marine Science, Townsville.

Avilés-Torres, S., J. J. Schmitter-Soto \& R. C. Barrientos-Medina. 2001. Patrones espaciales de la distribución de peces en lagunas costeras del sur de Quintana Roo, México. Hidrobiológica, 11: 141-148.

Baev, P. V. \& L. D. Penev. 1995. BIODIV 5.1 - program for calculating biological diversity parameters, similarity, niche overlap, and cluster analysis. Pensoft, Sofia.

Caballero-Vázquez, J. A., H. Gamboa-Pérez \& J. J. Schmitter-Soto. 2005. Composition and spatio-temporal variation of the fish community in the Chacmochuch Lagoon system, Quintana Roo, Mexico. Hidrobiológica, 15: 215-226.

Castro-Aguirre, J. L., H. Espinosa P. \& J. J. Schmitter-Soto. 1999. Ictiofauna estuarino-lagunar y vicaria de México. México: Ed. Limusa-Noriega. 711p.

Clarke, K. R. \& R. N. Gorley. 2001. Primer v5: User manual/tutorial. Primer-E Ltd. Plymouth, UK.

Cody, M. 1975. Towards a theory of continental species diversities. Pp. 214-257. In: M. Cody \& J. Diamond (Eds.) Ecology and evolution of communities. The Belknap Press of Harvard University, Cambridge, Mass. USA.

Colwell, R. K. 1994-2004. Estimates: statistical estimation of species richness and shared species from samples. (http:// viceroy.eeb.uconn.edu/estimates). [Persistent URL: (http:// purl.oclc.org/estimates)].

Davidar, P., B. Rajagopa, D. Mohandass, J. P. Puyravaud, R. Condit, S. J. Wright \& E. G. Leigh Jr. 2007. The effect of climatic gradients, topographic variation and species traits on the beta diversity of rain forest trees. Global Ecology and Biogeography. 16: 510-518.

Day, J. W. \& A. Yáñez-Arancibia. 1985. Coastal lagoons and estuarine as an environment for nekton. Pp.17-34. In: A. Yánez-Arancibia (Ed.), Fish community ecology in estuaries and coastal lagoons: towards an ecosystem integration. Editorial Universitaria, UNAM-PUAL-ICMyL, Mexico City.

Dorenbosch, M., M. G. G. Grol, M. J. A. Christianen, I. Nagelkerken \& G. van der Velde. 2005. Indo-Pacific seagrass beds and mangroves contribute to fish density and diversity on adjacent coral reefs. Marine Ecology Progress Series, 302: 63-76.

Franklin, J. F. 1993. Preserving biodiversity: species, ecosystems, or landscapes? Ecological Applications, 3: 202-205.

Fulton, C. J., D. R. Bellwood \& P. C. Wainwright. 2005. Wave energy and swimming performance shape coral reef fish assemblages. Proceedings of the Royal Society B, 272: 827-832.

Gaston, K. J. 2000. Global patterns in biodiversity. Nature, 405: 220-227.

Halffter, G. 1998. Una estrategia para medir la biodiversidad a nivel de paisaje. Pp. 3-18. In G. Halffter (Comp.). La Diversidad Biológica de Iberoamérica. Vol. II, Acta Zoológica Mexicana (n.s). Special number.

Harris, L. D. T., T. S. Hoctor \& S. E. Gergel. 1996. Landscape processes and their significance to biodiversity conservation. Pp. 319-347. In: Rhodes, O. E. J., R. K. Chesser \& M. H. Smith (Eds.). Population Dynamics in Ecological Space and Time. The University of Chicago Press, Chicago. 
Hawksworth, D. L. 1995. Biodiversity measurement and estimation. Chapman and Hall, London, 140p.

Hill, M. O. 1973. Diversity and evenness: a unifying notation and its consequences. Ecology, 54: 427-432.

Hughes, T. P., A. H. Baird, D. R. Bellwood, M. Card, S. R. Connolly, C. Folke, R. Grosberg, O. Hoegh-Gulberg, J. B. C. Jackson, J. Kleypas, J. M. Lough, P. Marshall, M. Nyström, S. R. Palumbi, J. M. Pandolfi, B. Rosen \& J. Roughgarden. 2003. Climate change, human impacts, and the resilience of coral ref. Science, 301: 929-933.

Huston, M. A. 2003. Heat and Biodiversity. Science, 299: 512-513.

Hutcheson, K. 1970. A test for comparing diversities based on the Shannon formula. Journal of Theoretical Biology, 29:151-154.

Jackson, R. B., S. R. Carpenter, C. N. Dahm, D. M. McKnight, R. J. Naiman, S. L. Postel \& S. W. Running. 2001. Water in a changing world. Ecological Applications, 1: 1027-1045.

Jankowski, J. E., A. L., Ciecka, N. Y. Meyer \& K. N. Rabenold. 2009. Beta diversity along environmental gradients: Implications of habitat specialization in tropical montane landscapes. Journal of Animal Ecology, 78: 315-327.

Loreau, M. 2000. Biodiversity and ecosystem functioning: recent theoretical advances. Oikos, 91: 3-17.

Loreau, M., S. Naeem, P. Inchausti, J. Bengtsson, J. Grime, A. Hector, D. Hooper, M. Huston, D. Raffaelli, B. Schmid, D. Tilman \& D. Wardle. 2001. Biodiversity and ecosystem functioning: current knowledge and future challenges. Science, 294: 804-808.

Magurran, A. E. 2004. Measuring biological diversity. Blackwell Publishing, Oxford, UK.

Myers, G. S. 1938. Fresh-water fishes and West Indian zoogeography. Annual Report of the Smithsonian Institution, 1937: 339-364.

Meekan, M. G., A. D. L. Steven \& M. J. Fortin. 1995. Spatial patterns in the distribution of damselfishes on a fringing coral reef. Coral Reefs, 14: 151-161.

Moreno, C. E. \& G. Halffter. 2001. Spatial and temporal analysis of alpha, beta and gamma diversities of bats in a fragmented landscape. Biodiversity and Conservation, 10: 376-382.

Mumby, P. J., J. A. Edwards, J. E. Arias-González, K. C. Lindeman, P. G. Blackwell, A. Gall, M. I. Gorczynska, A. R. Harbone, C. L. Pescod, H. Renten, C. C. Wabnitz \& G. Llewellyn. 2004. Mangrove enhance the biomass of coral ref. fish communities in the Caribbean. Nature, 427: 533-536.

Naeem, S. \& J. Wrigth. 2003. Disentangling biodiversity effects on ecosystem functioning: deriving solutions to a seemingly insurmountable problem. Ecology Letters, 6: 567-579.

Nagelkerken I., M. Dorenbosch, WCEP. Verberk, E. Cocheret de la Morinière \& G. van der Velde. 2000. Importance of shallowwater biotopes of a Caribbean bay for juvenile coral reef fishes: patterns in biotope association, community structure and spatial distribution. Marine Ecology Progress Series, 202: 175-192.

Nagelkerken, I., C. M. Roberts, G. van der Velde, M. Dorenbosch, M. C. van Riel, E. Cocheret de la Morinière \& P. H. Nienhuis. 2002. How important are mangrove and seagrass beds for coral-reef fish? The nursery hypothesis tested on an island scale. Marine Ecology Progress Series, 244: 299-305.

Nagelkerken, I. \& G. van der Velde. 2002. Do Non-Estuarine Mangroves Harbour Higher Densities of Juvenile Fish Than Adjacent Shallow-Water and Coral Reef Habitats in Curacao (Netherlands Antilles)?. Marine Ecology Progress Series, 245: 191-204.
Nogués-Bravo, D., M. B. Araújo, T. Romdal, \& C. Rahbek. 2008. Scale effects and human impact on the elevational species richness gradients. Nature, 453: 216-220.

Ordoñez-López, U. \& V. D. García-Hernández. 2005. Ictiofauna juvenil asociada a Thalassia testudinum en Laguna Yalahau, Quintana Roo. Hidrobiológica, 15: 195-204.

Pihl, L., H. Wennhage \& S. Nilson. 1994. Fish assemblages structure in relation to macrophytes and filamentous epiphytes in shallow nontidal rocky and soft bottom habitats. Environmental Biology of Fishes, 39: 271-288.

R Development Core Team, 2010. R: A Language and Environment for Statistical Computing, R Foundation for Statistical Computing, Vienna, Austria. ISBN 3-900051-07-0. *http:// www.R-project.org.

Reséndez-Medina, A. 1975. Lista preliminar de peces colectados en las lagunas de Nichupté y Bojórquez, Cancún, Quintana Roo, México. Anales del Instituto de Biología UNAM, Serie Zoológica, 46: 87-100.

Rodríguez, M. \& W. M. Lewis. 1994. Regulation and stability in fish assemblages of neotropical floodplain lakes. Oecologia, 99:166-180

Ricklefs, R. E. \& D. Schluter.1993. Species diversity in ecological communities: historical and geographical perspectives. University of Chicago (Press) USA.

Schluter, D. \& R. E. Ricklefs. 1993. Species diversity: an introduction to the problem. Pp. 1-12. In: Species diversity in ecological communities: historical and geographical perspectives, R. E. Ricklef \& D. Schluter (Eds). The University of Chicago Press, Chicago.

Schmitter-Soto J. J. 2009. Los arrecifes coralinos: evolución biológica, no creación divina. Ciencia, Conocimiento, Tecnología. http:/ /www.conocimientoenlinea.com/. 90: 77-80.

Soberón, J. \& P. Koleff. 1999. The national biodiversity information system of México. Pp. 586-595. In: Raven, P. H. \& T. Williams (Eds.). Contributions to the second national forum on biodiversity and human society: the quest for a sustainable future. National Academic Press, Washington, D.C.

Soberón, J. M. \& J. B. Llorente. 1993. The use of species accumulation functions for the prediction of species richness. Conservation Biology, $7:$ 480-488.

Sosa-Escalante, J. 2004. Estudio de la biodiversidad: Valoración y Medición. Manual of the Course. Ecology, Government of the State of Yucatan. México.

Tilman, D. 2001. Functional diversity. Pp. 109-120. In: Huntly J. \& S. A. Levin (Eds.). Encyclopedia of Biodiversity, Vol. 3. Academic Press, San Diego, CA.

Tuomisto, H. 2010a. A diversity of beta diversities: straightening up a concept gone away. Part 1. Defining beta diversity as a function of alpha and gamma diversity. Ecography, 33: 2-22.

Tuomisto, H. 2010b. A diversity of beta diversities: straightening up a concept gone away. Part 2. Quantifying beta diversity and related phenomena. Ecography, 33: 23-45.

Universidad de Quintana Roo. 1999. Propuesta para la elaboración del programa de manejo del Área Natural Protegida sistema lagunar Chacmochuch. UQROO Chetumal, Quintana Roo, México, 7p.

Whittaker, R. H. 1972. Evolution and measurement of species diversity. Taxon, 21: 213-251.

Submitted August 23, 2010

Accepted November 10, 2011

Published March 30, 2012 